\title{
Danuta Bąk
}

\author{
Przychodnia Rehabilitacyjno-Lecznicza przy ZPH Wodex, Stalowa Wola
}

\section{POMOC RODZINY W OKRESIE REKONWALESCENCJI W OCENIE PACJENTEK PO PRZEBYTEJ MASTEKTOMII}

\author{
adres do korespondencji: \\ Danuta Bąk, ul. Hutnicza 15, 37-403 Pysznica \\ e-mail:dan.bak@wp.pl
}

\section{Streszczenie}

Wprowadzenie: Choroba nowotworowa wymaga zarówno od osoby chorej, jak i członków jej rodziny wielu wyrzeczeń, zmiany priorytetów życiowych oraz nabywania nowych kompetencji medyczno-opiekuńczych. Celem niniejszego opracowania jest przedstawienie roli rodziny w kształtowaniu pozytywnych efektów rekonwalescencji u kobiet chorych na nowotwór piersi, po zabiegu mastektomii.

Materiał i metody: W przeprowadzonym badaniu wzięło udział 50 kobiet: członkinie Klubu Amazonek oraz kobiety uczestniczące w dwutygodniowym turnusie rehabilitacyjnym po zabiegu mastektomii. Dominującą metodą badawczą była metoda monograficzna oraz techniki takie jak: badania kwestionariuszowe, wywiad standaryzowany z elementami pogłębionego wywiadu swobodnego oraz obserwacja uczestnicząca.

Wyniki oraz wnioski: Przeprowadzone badania pozwoliły stwierdzić, że do uzyskania pozytywnych efektów rekonwalescencji po mastektomii konieczne jest: odciążenie chorej kobiety od obowiązków domowych; pomoc medyczna, opiekuńcza oraz emocjonalna członków rodziny oraz samodyscyplina i wysoka odporność psychiczna chorej.

Słowa kluczowe: mastektomia, nowotwór, pomoc, rodzina 


\section{Wprowadzenie}

Liczba zachorowań na nowotwory złośliwe piersi w Polsce stale rośnie (w 2006 roku wynosiła 13 322, natomiast prognoza na rok 2025 to 21 108). Ponadto największy przyrost zachorowalności obserwuje się $\mathrm{w}$ grupie kobiet między 50 a 69 rokiem życia [1]. Choroba ta dotyka więc kobiety, które pełnią wiele funkcji rodzinnych. Są one, bowiem żonami, matkami i babciami, a więc choroba nowotworowa oraz jej następstwa wywołują szereg zmian w funkcjonowaniu całej rodziny. W wielu krajach, w tym również w Polsce, kobieta ma w rodzinie obowiązki związane $\mathrm{z}$ opieką, wymagające zdolności poświęcania się dla innych oraz związane z dbaniem o dom [2]. Jednak w sytuacji, kiedy zostaje ona dotknięta chorobą nowotworową, wówczas priorytety oraz podział ról w rodzinie muszą diametralnie się zmienić tak, aby chora została odciążona od wszystkich obowiązków domowych i mogła skupić się jedynie na swojej rekonwalescencji oraz powrocie do zdrowia. W czasie trwania choroby nowotworowej zmienia się, więc sposób funkcjonowania rodziny jako systemu. Rodzina, chorej na nowotwór piersi kobiety, powinna wprowadzić ułatwienia dla jej codziennego funkcjonowania, uwzględniając długoterminowy horyzont czasowy [3]. Cała reorganizacja dotychczasowego funkcjonowania rodziny, powinna nastąpić tuż po otrzymaniu przez chorą diagnozy oraz decyzji i planów dotyczących rodzaju stosowanego leczenia. Naturalnie całemu procesowi będą towarzyszyły smutek, lęk a niekiedy nawet gniew, odczuwane zarówno przez chorą jak i jej najbliższych [4]. Dlatego też, tak ważne dla rodziny dotkniętej chorobą nowotworową jest wsparcie emocjonalne, informacyjne, kompetencyjne od specjalistów, między innymi lekarzy i rehabilitantów zajmujących się chorą pacjentką.

Ważna jest również konieczność nabywania przez członków rodziny chorej na nowotwór piersi kobiety nowych kompetencji medyczno-opiekuńczych ukierunkowanych na poprawę stanu jej zdrowia. Kompetencje te powinny dotyczyć zarówno zakresu opieki związanej z wystąpieniem choroby nowotworowej, jak i pomocy w odzyskiwaniu zdrowia oraz kompensowania utraconych funkcji [2]. Wystąpienie choroby nowotworowej, lęk przed śmiercią bliskiej osoby oraz związane z tym emocje są wyzwaniami, z którymi, niektóre rodziny radzą sobie dobrze, a niektóre zdecydowanie gorzej. Dlatego też, w tak trudnej sytuacji przydatne może okazać się wsparcie psychologa rodzinnego [5]. Skuteczność leczenia raka piersi jest silnie powiązana nie tylko z samym momentem diagnozy, ale również z czasem, jaki upływa od momentu zdiagnozowania choroby do momentu rozpoczęcia jej leczenia [6]. Dlatego niezmiernie ważne jest, aby rodzina chorej potrafiła poprawić jej stan emocjonalny, udzielić wsparcia oraz zmobilizować ją do jak najszybszego rozpoczęcie procesu leczenia. Cała rodzina powinna stać się więc partnerem $\mathrm{w}$ profesjonalnym postępowaniu medyczno-opiekuńczym, wynikającym z wystąpienia w rodzinie choroby nowotworowej [7]. 
Celem niniejszego opracowania było zbadanie roli pomocy rodziny w kształtowaniu pozytywnych efektów rekonwalescencji po mastektomii.

\section{Material i metody}

W badaniu wzięło udział 50 kobiet, rekrutowane spośród członkiń Klubu Amazonek oraz kobiet uczestniczących w dwutygodniowym turnusie rehabilitacyjnym po zabiegu mastektomii. Połowę badanych (50\%) stanowiły kobiety w przedziale wiekowym 51-60 lat. Następne 20\% reprezentowało przedział wiekowy 61 i więcej, kolejne $20 \%$ to kobiety z przedziału wiekowego $31-40$ lat, zaś pozostałe $10 \%$ to kobiety w wieku od 41 do 50 lat. Udział w badaniu był dobrowolny i anonimowy. $80 \%$ badanych kobiet poddane zostało zabiegowi mastektomii radykalnej, zaś 20\% zabiegowi oszczędzającemu pierś. Czas, jaki upłynął od zabiegu mastektomii wynosit: dla $45 \%$ badanych - od 3 do 5 lat, dla $33 \%$ badanych powyżej 5 lat, zaś dla $22 \%$ badanych od 1 roku do 2,5.

Dominującą metodą badawczą była metoda monograficzna, pozwalająca zbadać jakość życia kobiet po mastektomii z wykorzystaniem takich technik jak: badanie kwestionariuszowe (wykorzystano kwestionariusz opracowany przez autorkę niniejszego opracowania - fizjoterapeutkę, bezpośrednio uczestniczącą $\mathrm{w}$ rehabilitacji biorących udział w badaniu kobiet), wywiad standaryzowany z elementami pogłębionego wywiadu swobodnego oraz obserwacja uczestnicząca.

\section{Wyniki}

Przedmiotem badań wykorzystanych w niniejszym opracowaniu było dowiedzenie hipotezy, że pomoc rodziny jest kluczowym determinantem pozytywnych efektów rekonwalescencji u kobiet po mastektomii.

W pierwszej części badania skupiono się na zmianach priorytetów i ról $\mathrm{w}$ rodzinie w związku z wystąpieniem choroby oraz na pomocy medyczno-opiekuńczej, jakiej udzielali członkowie rodziny chorej na nowotwór kobiecie.

Połowa biorących udział w badaniu kobiet wykonywała ćwiczenia usprawniające po zabiegu mastektomii w domu kilka razy w tygodniu (ćwiczenia oddechowe, automasaż, drenaż limfatyczny manualny, pozycje ułożeniowe), przy czym $46 \%$ badanych w ćwiczeniach domowych kilka razy w tygodniu pomagali członek/członkowie rodziny. Ponadto $26 \%$ otrzymywało pomoc w ćwiczeniach rehabilitacyjnych codziennie (Tab. 1). Ważnym faktem jest, że wszystkie ankietowane pacjentki podkreślały, iż każda $\mathrm{z}$ nich otrzymywała $\mathrm{w}$ jakimś stopniu wsparcie i pomoc rodziny.

Z przeprowadzonych badań wynika, że pacjentki po zabiegu korzystały również z rehabilitacji ambulatoryjnej (ćwiczenia w odciążeniu, samowspoma- 
gane, ćwiczenia grupowe, drenaż limfatyczny pneumatyczny, kompresioterapia, ćwiczenia ogólnousprawniające); $28 \%$ z nich codziennie, 52\% kilka razy w tygodniu (Tab. 2).

Ważnym aspektem w leczeniu nowotworu piersi pozostaje subiektywna ocena kobiet własnej sprawności fizycznej po zabiegu mastektomii.

$\mathrm{Z}$ przeprowadzonego badania wynika, że $40 \%$ badanych oceniało swoją sprawność fizyczną po zabiegu jako dobrą, kolejne 36\% jako przeciętną, zaś ostatnie $24 \%$ jako bardzo dobrą. Warto więc zauważyć, że żadna z ankietowanych nie określiła swojej sprawności fizycznej po zabiegu jako słabej lub bardzo słabej (Tab. 3).

Ważny element niniejszego badania stanowiły pytania dotyczące stopnia odciążenia chorej na nowotwór kobiety przez rodzinę od obowiązków domowych.

W tym obszarze uzyskano bardzo zadowalające wyniki, bowiem $60 \%$ badanych zadeklarowało, że członkowie rodziny w dużej mierze przejęli ich dotychczasowe obowiązki domowe, zaś $30 \%$ badanych zostało odciążonych przez rodzinę całkowicie. $\mathrm{Z}$ kolei tylko $10 \%$ otrzymało od rodziny pomoc nieznaczną (Tab. 4).

W kwestii rekonwalescencji po mastektomii niezwykle ważne okazuje się informowanie chorych pacjentek o zasadach postępowania w życiu codziennym przez specjalistów, takich jak lekarze prowadzący czy fizjoterapeuci. Z przeprowadzonego badania wynika, że 100\% kobiet biorących udział w badaniu otrzymało konieczne informacje o ćwiczeniach rehabilitacyjnych i zasadach rekonwalescencji, których powinny przestrzegać w warunkach domowych. Dzięki spełnieniu przez specjalistów funkcji informacyjnych, zarówno chorym na nowotwór piersi kobietom, jak i ich rodzinom dostarczono wszelkich informacji, które były niezbędne do przeorganizowania ich codziennego życia i dostosowania się do nowej sytuacji.

Kolejna część badania dotyczyła samodyscypliny chorych na nowotwór kobiet, ich odporności psychicznej oraz postrzegania zmian wizerunkowych własnego ciała po mastektomii. Na pytanie dotyczące stanu psychicznego po zabiegu $42 \%$ badanych nie zaobserwowało u siebie zmian, następne $30 \%$ zaobserwowało zmiany związane z reorganizacja priorytetów życiowych, 18\% wykazywało optymizm oraz nadzieję na poprawę stanu zdrowia. Tylko $10 \%$ kobiet na to pytanie udzielało odpowiedzi, że po zabiegu częściej są smutne i odczuwają lęk (Tab. 5).

W kolejnym pytaniu, kobiety zapytano o wsparcie psychiczne udzielone im przez bliskich w czasie trwania choroby i rehabilitacji. Odpowiedzi na to pytanie dowodzą, że ponad połowa (52\%) badanych znalazła u bliskich wsparcie psychiczne, natomiast tylko 8\% kobiet czuło się osamotnionych w chorobie (Tab. 6).

Niezwykle ważna jest też potrzeba motywowania chorej kobiety przez rodzinę do regularnego wykonywania ćwiczeń oraz innych czynności procesu rekonwalescencji. Z badań wynika, że 64\% kobiet ma własną wewnętrzną mobilizację do ćwiczeń, zaś $28 \%$ potrzebuje mobilizacji ze strony bliskich (Tab. 7). 
Tabela 1. Częstotliwość wykonywania ćwiczeń usprawniających w domu

\begin{tabular}{llclc}
\hline Pytanie & $\begin{array}{l}\text { Jak często wykonuje Pani ćwi- } \\
\text { czenia usprawniające w domu? }\end{array}$ & $\begin{array}{c}\text { Liczba } \\
\text { osób }\end{array}$ & $\begin{array}{l}\text { Jak często pomaga Pani przy } \\
\text { ćwiczeniach usprawniających } \\
\text { rodzina? }\end{array}$ & $\begin{array}{c}\text { Liczba } \\
\text { osób }\end{array}$ \\
\hline Odpo- & Codziennie & 15 & Codziennie & 13 \\
wiedź & Kilka razy w tygodniu & 25 & Kilka razy w tygodniu & 23 \\
& Raz w tygodniu & 10 & Raz w tygodniu & 14 \\
& Raz w miesiącu & 0 & Wcale & 0 \\
& Nie wykonuje ćwiczeń w domu & 0 & & \\
\hline
\end{tabular}

Tabela 2. Częstotliwość korzystania z rehabilitacji ambulatoryjnej

\begin{tabular}{llc}
\hline Pytanie & Jak często korzysta Pani z rehabilitacji ambulatoryjnej? & $\begin{array}{c}\text { Liczba } \\
\text { osób }\end{array}$ \\
\hline Odpowiedź & Codziennie & 14 \\
& Kilka razy w tygodniu & 26 \\
& Raz w tygodniu & 10 \\
& Wcale & 0 \\
\hline
\end{tabular}

Tabela 3. Subiektywna ocena sprawności fizycznej po zabiegu mastektomii

\begin{tabular}{llc}
\hline Pytanie & Jak ocenia Pani swoją sprawność fizyczną po zabiegu? & $\begin{array}{c}\text { Liczba } \\
\text { osób }\end{array}$ \\
\hline Odpowiedź & Dobra & 20 \\
& Przeciętna & 18 \\
& Bardzo dobra & 12 \\
& Słaba & 0 \\
& Bardzo słaba & 0 \\
\hline
\end{tabular}

Tabela 4. Odciążenie chorej od obowiązków domowych

\begin{tabular}{llc}
\hline Pytanie & Czy i w jakim stopniu została Pani odciążona przez rodzinę od & $\begin{array}{c}\text { Liczba } \\
\text { osób }\end{array}$ \\
\hline Odpowiązków domowych? & 30 \\
& Tak, w dużej mierze & 15 \\
& Tak, całkowicie & 5 \\
& Nieznacznie & 0 \\
\hline
\end{tabular}

Tabela 5. Subiektywna ocena stanu psychicznego pacjentek po mastektomii

\begin{tabular}{llc}
\hline Pytanie & Jak Pani ocenia swój stan psychiczny po zabiegu? & $\begin{array}{c}\text { Liczba } \\
\text { osób }\end{array}$ \\
\hline Odpowiedź & Bez zmian & 21 \\
& Zmiana priorytetów życiowych & 15 \\
& Częściej bywam smutna, odczuwam lęk & 5 \\
& Pełna entuzjazmu - dobre myśli & 9 \\
\hline
\end{tabular}


Tabela 6. Wsparcie psychiczne udzielone przez bliskich

\begin{tabular}{llc}
\hline Pytanie & Czy znalazła Pani wsparcie psychiczne u bliskich? & $\begin{array}{c}\text { Liczba } \\
\text { osób }\end{array}$ \\
\hline Odpowiedź & Tak, bardzo duże & 14 \\
& Tak & 26 \\
& Nie czułam się wspierane przez rodzinę & 6 \\
& Czułam się osamotniona w chorobie & 4 \\
\hline
\end{tabular}

Tabela 7. Motywacja do rehabilitacji

\begin{tabular}{llc}
\hline Pytanie & Czy potrzebuje Pani motywacji rodziny do rehabilitacji? & $\begin{array}{c}\text { Liczba } \\
\text { osób }\end{array}$ \\
\hline Odpowiedź & Nie, sama potrafię zmotywować się do ćwiczeń & 32 \\
& Tak, rodzina mobilizuje mnie do ćwiczeń & 14 \\
& Mimo namowom rodziny rzadko ćwiczę & 1 \\
& Brak mi motywacji & 3 \\
\hline
\end{tabular}

Tabela 8. Sposób postrzegania zmian wizerunkowych własnego ciała po mastektomii

\begin{tabular}{llc}
\hline Pytanie & Czy po zabiegu zmienił się sposób postrzegania przez Panią własnego & $\begin{array}{c}\text { Liczba } \\
\text { osób }\end{array}$ \\
\hline Odpowiedź & Taka, bardziej o siebie dbam & 2 \\
& Tak, mam kompleksy z powodu braku piersi & 20 \\
& Mimo zmian w wyglądzie czuję się akceptowana & 18 \\
& Nie czuję się już atrakcyjna & 10 \\
\hline
\end{tabular}

Tabela 9. Czynniki przyczyniające się w największym stopniu do poprawy stanu zdrowia pacjentek

\begin{tabular}{llc}
\hline Pytanie & Który z poniższych czynników przyczynił się najbardziej do poprawy & $\begin{array}{c}\text { Liczba } \\
\text { osób }\end{array}$ \\
\hline Odpowiedź & Psychiczne wsparcie rodziny & 13 \\
& Sumienne wykonywanie ćwiczeń i rehabilitacja & 5 \\
& Leczenie medyczne i farmakologiczne & 30 \\
& Pozytywne nastawienie & 2 \\
\hline
\end{tabular}

Tabela 10. Ocena zdolności radzenia sobie ze stresem i sytuacjami kryzysowymi

\begin{tabular}{llc}
\hline Pytanie & Jak przed chorobą oceniałaby Pani swoją zdolność do radzenia sobie & $\begin{array}{c}\text { Liczba } \\
\text { osób }\end{array}$ \\
\hline Zdpowiedź & Bardzo dobrze, jestem odporna na stres & 8 \\
& Adekwatnie do sytuacji & 19 \\
& Często nie radzę sobie ze stresem i szukam wsparcia u bliskich & 12 \\
& W ogóle nie radzę sobie ze stresem, często popadam w depresję & 11 \\
\hline
\end{tabular}


Tabela 11. Postrzeganie przez pacjentki zmian zaistniałych w ich rodzinach na skutek choroby nowotworowej

\begin{tabular}{llc}
\hline Pytanie & $\begin{array}{l}\text { Jak postrzega Pani zmiany zaistniałe w Pani rodzinie na skutek } \\
\text { choroby? }\end{array}$ & $\begin{array}{c}\text { Liczba } \\
\text { osób }\end{array}$ \\
\hline Odpowiedź & $\begin{array}{l}\text { Cieszy mnie fakt, że rodzina pomaga mi we wszystkich czynnościach } \\
\text { dnia codziennego }\end{array}$ & 30 \\
& Nie odczułam zmian, ponieważ obowiązki w mojej rodzinie zawsze & 13 \\
& były podzielone & \\
& Czuję się nie potrzebna & 5 \\
& Nie zauważyłam zmian, gdyż podział obowiązków w mojej rodzinie \\
& się nie zmienił
\end{tabular}

W związku z tym, że zabieg mastektomii powoduje okaleczenie ciała chorej kobiety, ważną część niniejszego badania stanowiły pytania dotyczące sposobu postrzegania oraz akceptacji ciała po zabiegu. Wykazano, że $40 \%$ badanych ma kompleksy z powodu braku piersi, a 36\% czuje się akceptowana, mimo zmian w wyglądzie. Z kolei $20 \%$ pacjentek stwierdza, że po amputacji piersi nie czuje się atrakcyjna (Tab. 8).

Kolejną kwestią poddaną badaniu było wyłonienie czynników, które według badanych kobiet najbardziej przyczyniły się do poprawy stanu ich zdrowia. Zgodnie z oczekiwaniami najwięcej kobiet (60\%) za czynnik najważniejszy w procesie odzyskiwania zdrowia, uważa leczenie medyczne oraz farmakologiczne, jednak ważny jest fakt, że już na drugim miejscu, czynnikiem najważniejszym było wsparcie rodziny (według $26 \%$ badanych) (Tab. 9).

Ostatni etap badań dotyczył znaczenia, jakie w procesie leczenia nowotworów piersi mają czynniki warunkujące poszukiwanie oraz przyjmowanie pomocy, jak też uwarunkowań osobistych chorych kobiet, określających predyspozycje do radzenia sobie ze stresem oraz sytuacjami kryzysowymi. Punktem wyjściowym w tej kwestii była subiektywna ocena pacjentek zdolności radzenia sobie ze stresem i trudnymi sytuacjami przed chorobą. Jak wynika z badań, 38\% kobiet oceniało swoje zdolności radzenia sobie ze stresem jako adekwatne do sytuacji, 24\% przyznało, że często przed chorobą nie radziło sobie ze stresem i szukało wparcia u bliskich, $22 \%$ przyznało, że nie radziło sobie ze stresem, popadając niekiedy w stany depresyjne. $16 \%$ kobiet oceniło swoje zdolności radzenia sobie ze stresem przed chorobą jako bardzo dobre (Tab. 10).

Oprócz samych zmian następujących w rodzinie na skutek wystąpienia choroby nowotworowej jednego z jej członków, ważne jest to, jak zmiany te postrzega chora na nowotwór piersi kobieta. Z badań wynika, że $60 \%$ badanych kobiet cieszy fakt pomocy członków rodziny we wszystkich czynnościach dnia codziennego, z kolei $26 \%$ badanych nie odczuło dużych zmian, bowiem w ich rodzinach zawsze istniał sprawiedliwy podział obowiązków. Warto podkreślić fakt, że wśród badanych 10\% kobiet zadeklarowało, że w związku z odciążeniem ich w czynnościach domowych, zaczęły czuć się niepotrzebne (Tab. 11). 
Na podstawie wyników przeprowadzonych badań można sformułować wnioski dotyczące jakości życia kobiet po zabiegu mastektomii z powodu raka piersi oraz roli ich rodzin w kształtowaniu pozytywnych efektów rekonwalescencji:

- im bardziej rodzina odciąża chorą z obowiązków dnia codziennego, tym więcej czasu może poświęcić ona na proces rekonwalescencji i rehabilitacji po zabiegu mastektomii, a tym samym proces leczenia może być skuteczniejszy, a proces dochodzenia do zdrowia szybszy,

- im większe wsparcie chora uzyskuje od rodziny, tym lepsze są wyniki jej leczenia oraz rehabilitacji,

- im kobieta czuje się silniejsza psychicznie i lepiej radzi sobie z sytuacjami kryzysowymi, tym lepiej znosi trudy diagnozy i leczenia nowotworu piersi,

- im większe wsparcie i pomoc otrzymuje chora od rodziny, tym bardziej akceptuje nową sytuację oraz zmiany wizerunkowe własnego ciała,

- im częściej chora kobieta wykonuje ćwiczenia rehabilitacyjne w domu, tym lepiej ocenia swoją sprawność fizyczną po zabiegu,

- im lepszy stan psychiczny pacjentki po zabiegu, tym częściej i chętniej podejmuje ona rehabilitację zarówno ambulatoryjną, jak i w warunkach domowych,

- im chętniej chora kobieta przyjmuje pomoc od bliskich, tym lepiej postrzega swoje samopoczucie po zabiegu mastektomii,

- im bardziej rodzina mobilizuje chorą pacjentkę oraz pomaga jej w wykonywaniu ćwiczeń rehabilitacyjnych w domu, tym lepiej chora ocenia swoją sprawność fizyczną po procesie rekonwalescencji.

\section{Dyskusja}

Choroba nowotworowa pojawiająca się w rodzinie wymaga od wszystkich jej członków poświęcenia i przeorganizowania życia domowego. Aby dotknięta nowotworem piersi kobieta mogła w pełni realizować proces leczenia oraz rekonwalescencji, konieczne są zarówno nowy podział ról w rodzinie, jak też pomoc i wsparcie wszystkich członków rodziny w mobilizacji do rehabilitacji, w odciążeniu od obowiązków domowych oraz w utrzymaniu stabilności emocjonalnej chorej kobiety.

Przeprowadzone badania dowodzą, że w celu uzyskania pozytywnych efektów rekonwalescencji po mastektomii nieodzowne staje się przekazanie obowiązków kobiety zmagającej się z nowotworem innym członkom rodziny oraz pomoc jej zarówno w rehabilitacji, jak i w czynnościach dnia codziennego. Aby pomoc ta mogła być pełna i profesjonalna, członkowie rodziny chorej muszą nabywać nowe kompetencje: medyczne, opiekuńcze oraz rehabilitacyjne. Informacje na ten temat mogą czerpać zarówno od lekarzy prowadzących chorą, pielęgniarek, rehabilitantów oraz z literatury fachowej. Okazało się również, że bar- 
dzo ważnym elementem, który przyczynia się do wysokiej jakości życia kobiety po zabiegu mastektomii, jest jej dowartościowywanie przez członków rodziny oraz zapewnienie jej pełnej akceptacji i poczucia bezpieczeństwa.

Warto zwrócić uwagę na fakt, iż część kobiet biorących udział w badaniu należała do Klubu Amazonek. Kluby Amazonek są organizacjami stanowiącymi źródło wsparcia dla kobiet chorych na nowotwór piersi. Dają one chorym większe możliwości dostępu do informacji medycznych, rehabilitacyjnych, psychologicznych, do warsztatów terapeutycznych i aktywizacyjnych. Wydarzenia organizowane przez Kluby Amazonek jednoczą grupy kobiet po amputacji piersi, dzięki czemu mogą one wymieniać się swoimi spostrzeżeniami oraz doświadczeniami i udzielać sobie wzajemnego wsparcia. Dzięki przynależności do Klubu Amazonek chore mogą w otwarty sposób rozmawiać o swojej chorobie, dzięki czemu bardzo często przezwyciężają „,bariery cierpienia” [8].

Kolejna hipoteza badawcza, która została potwierdzona przeprowadzonymi badaniami to fakt, że w przebiegu choroby nowotworowej piersi niezwykle ważna okazuje się samodyscyplina chorej, jej odporność psychiczna oraz sposób postrzegania zmian wizerunkowych własnego ciała po mastektomii. Okazało się, że bardzo mało kobiet biorących udział w badaniu odczuwało smutek i lęk związany z zaistniałą sytuacja, a czynnikiem, który miał na to wpływ było wsparcie emocjonalne oraz pomoc egzystencjalna rodziny.

Choroba nowotworowa w znaczący sposób zaburza pojmowanie oraz wizerunek własnego ciała. Chory pacjent utożsamia nowotwór z niepożądanym produktem własnego ciała, które od tej pory staje się dla niego źródłem choroby i zagrożenia [9].

Przeprowadzone badania potwierdziły również, że dla kobiet dotkniętych nowotworem piersi poza leczeniem medycznym, farmakologicznym oraz rehabilitacyjnym, bardzo ważne jest wsparcie psychiczne i emocjonalne rodziny. Bez stabilności emocjonalnej oraz nadziei na wyzdrowienie, leczenie nie przynosiłoby w pełni oczekiwanych efektów.

W przypadku nowotworów piersi duży nacisk kładziony jest na jakość życia pacjentek, zarówno w trakcie jak i po leczeniu. W związku z tym, pojęcie jakości życia staje się centralnym zagadnieniem, które ma zasadnicze znaczenia dla postępowania terapeutycznego. Najważniejszym aspektem analizowanym w kwestii jakości życia chorych na nowotwór kobiet, jest aspekt psychospołeczny [10]. Najważniejszym elementem tego aspektu jest rodzina chorej pacjentki, jej nastawienie i sposób radzenia sobie ze stresem i niedogodnościami psychicznymi związanymi z zaistniałą sytuacją. Dzięki przeprowadzonemu badaniu, stwierdzono, że na stopień jakości życia pacjentki po mastektomii ma wpływ liczba stosowanych metod rehabilitacji oraz ilość poświęconego jej czasu, a mianowicie im więcej czasu pacjentki poświęcały na rehabilitację oraz im więcej metod rekonwalescencji stosowały w procesie leczenie, tym osiągały wyższą jakość życia zarówno w chorobie, jak i po chorobie. 
Wyniki przeprowadzonych badań dały również możliwość potwierdzenia hipotezy, że duże znaczenie w procesie leczenia nowotworów piersi po zabiegu mastektomii mają czynniki warunkujące poszukiwanie i przyjmowanie pomocy oraz uwarunkowania osobiste chorej, określające predyspozycje do radzenia sobie z sytuacjami kryzysowymi oraz stresem. Tak więc, aby w nowej sytuacji - sytuacji choroby chora mogła zachować jak najlepsze samopoczucie, ważne jest, aby umiała przyjmować oferowaną jej pomoc od członków rodziny. Jest to dla kobiet zadanie niekiedy bardzo trudne, bowiem w związku ze sprawowanymi przez nie funkcjami rodzinnymi (żon, matek) najczęściej to one są osobami, które w rodzinie sprawują funkcje opiekuńcze i oferują swoją pomoc w każdym wymiarze życia rodzinnego. Natomiast w nowej sytuacji to one muszą pozwolić swoim najbliższym na zaopiekowanie się sobą.

Biorąc pod uwagę fakt, że wsparcie emocjonalne polega głównie na stwarzaniu innej osobie okazji do bezpiecznego uwidaczniania i odreagowywania negatywnych emocji (takich jak strach, smutek, czy złość) [11], jest ono niezbędne, aby chora na nowotwór kobieta mogła przedstawić swoim najbliższym obawy oraz źródła jej strachu, a oni pomogli uporać się jej z negatywnymi emocjami i nastawić możliwie najbardziej optymistycznie na najbliższe wydarzenia związane $\mathrm{z}$ chorobą.

Niekiedy jednak pomimo usilnych starań rodziny, kobieta zmagająca się $\mathrm{z}$ nowotworem nie radzi sobie emocjonalnie i popada $\mathrm{w}$ zaburzenia depresyjne związane z jej stanem zdrowia. Dzieje się tak dlatego, że nowotwór jest postrzegany jako choroba, która zagraża życiu, a jej rozpoznanie nadal wywołuje wśród chorych lęk przed śmiercią. W związku z tym uwaga zarówno samych chorych, ich rodzin jak i lekarzy powinna być skupiona głównie na opracowywaniu efektywnych modeli leczenia, które zapewnią chorym lepszą jakość życia [12].

Okazuje się że najlepsze, co mogą dla siebie zrobić chora kobieta i jej bliscy, to otwarte rozmowy o swoich uczuciach (o lękach, frustracji, smutku). Otwarte wypowiadania się o negatywnych emocjach pozwala całej rodzinie stopniowo uwalniać się od niewypowiedzianego ciężaru zmartwień. Na takiej właśnie otwartości należy budować w rodzinach dotkniętych chorobą nowotworową nadzieję na dobrą przyszłość, wyzdrowienie oraz powrót do życia sprzed choroby [12].

Niezmiernie ważna w przypadku nowotworu piersi jest profilaktyka, czyli okresowe badania umożliwiające jak najwcześniejsze wykrycie zmian nowotworowych. Do profilaktyki - oprócz badań diagnostycznych - zalicza się samobadanie piersi kobiet. Każda kobieta powinna regularnie poddawać się badaniom profilaktycznym, a jeśli zdarza się jej o tym zapomnieć, obowiązkiem członków jej najbliższej rodziny jest przypominanie oraz nakłanianie do regularnych badań profilaktycznych, zwłaszcza kiedy kobiety te są szczególnie narażone na zachorowanie (znajdują się w przedziale wiekowym 50-69 lat lub w ich rodzinach obserwowano zachorowania na raka piersi). 
Podsumowując, uzyskane wyniki potwierdzają główną hipotezę badawczą, wskazującą, że pomoc rodziny jest kluczowym determinantem pozytywnych efektów rekonwalescencji u kobiet po mastektomii. Tak więc, aby chore na nowotwór kobiety widziały sens w poddaniu się leczeniu medycznemu, farmakologicznemu oraz rehabilitacyjnemu, konieczne jest wsparcie ich najbliższych, zarówno egzystencjalne wyrażające się w pomocy dnia codziennego, jak i duchowe, obejmujące pomoc $\mathrm{w}$ radzeniu sobie $\mathrm{z}$ emocjami, motywację do leczenia i rekonwalescencji oraz kształtowanie pozytywnego nastawienia i nadziei chorej na wyzdrowienie.

\section{Wnioski}

Nowotwór zdiagnozowany u danej osoby zmienia dotychczasowe życie całej jej rodziny. W przypadku nowotworu piersi, z którym zmagają się kobiety nowa sytuacja wymaga znaczących modyfikacji w podziale ról i obowiązków rodziny. Od momentu diagnozy kobieta, która do tej pory była opiekuńczą ostoją rodziny sama zaczyna potrzebować opieki i wsparcia. W procesie tym nieocenioną rolę spełniają więc jej najbliżsi. Wyniki przeprowadzonych badań, pozostające w zgodności z publikacjami innych autorów pozwalają potwierdzić, że do uzyskania oczekiwanych efektów rekonwalescencji po zabiegu mastektomii konieczne jest odciążenie kobiety chorej z dotychczasowych obowiązków domowych, tak aby dodatkowy czas uzyskany w ten sposób mogła w pełni przeznaczyć na działania prowadzące ją do wyzdrowienia. Niezwykle ważne okazuje się w tym procesie nabywanie przez członków rodziny chorej nowych kompetencji, dzięki którym będą mogli pomagać jej w codziennej rehabilitacji.

Aby proces leczenia nie był zakłócany negatywnymi stanami emocjonalnymi związanymi z wystąpieniem choroby nowotworowej, bardzo ważna jest odporność psychiczna chorej oraz stopień wsparcia, jaki otrzymuje od najbliższych. Warto zauważyć, że oprócz negatywnych skutków emocjonalnych, takich jak strach czy smutek, nierozerwalnie związanych z wystąpieniem w rodzinie choroby nowotworowej, w tym procesie pojawiają się aspekty pozytywne, takie jak większa bliskość rodzinna oraz pogłębienie relacji pomiędzy wszystkimi członkami rodziny.

Aby kobieta zmagająca się z tak poważna chorobą, jaką jest nowotwór, mogła realizować zalecone metody leczenia oraz proces rehabilitacji, musi czuć się w pełni akceptowana i doceniana przez najbliższe otoczenie, zwłaszcza członków rodziny. Dzięki temu, uda się jej ograniczyć do minimum występowanie stanów depresyjnych. W kwestii unikania przez chorą negatywnych stanów emocjonalnych ważne są również jej uwarunkowania osobiste, które określają predyspozycje do radzenia sobie ze stresem. Kobiety które przed chorobą umiały dobrze radzić sobie z sytuacjami kryzysowymi, z pewność lepiej zniosą trudy 
związane z chorobą nowotworową niż kobiety, które od zawsze nie radziły sobie ze stresem.

Niezwykle ważnym wnioskiem wynikającym z przeprowadzonych badań jest stwierdzenie, że w procesie leczenia nowotworów piersi zaraz obok ogromnego znaczenia leczenia medycznego i farmakologicznego, duże znaczenie ma wsparcie psychiczne i emocjonalne rodziny.

Amputacja piersi będąca następstwem choroby nowotworowej jest kolejnym wyzwaniem, z jakim musi zmagać się chora. Zmiany wizerunkowe ciała po mastektomii są bowiem kwestią, z którą niektóre kobiety nie radzą sobie, popadając w kompleksy oraz uważając się za nieatrakcyjne. Jednakże uzyskane wyniki pozwoliły sformułować wniosek, że to właśnie pomoc i wsparcie rodziny mają bardzo duży wpływ na to, aby tych kompleksów oraz obniżenia poczucia własnej wartości kobieta nie odczuwała.

$\mathrm{Na}$ podstawie wszystkich wyżej przedstawionych wniosków można stwierdzić, że pomoc rodziny jest niewątpliwie kluczowym determinantem pozytywnych efektów rekonwalescencji u kobiet po mastektomii.

\section{Bibliografia}

1. Didkowska J, Wojciechowska U, Zatoński W, Prognozy zachorowalności i umieralności na nowotwory zlośliwe w Polsce do 2025 roku, Publikacja wydana w ramach zadania „Rejestracja nowotworów złośliwych” Narodowego Programu Zwalczania Chorób Nowotworowych, Warszawa 2009.

2. Kawczyńska-Butrym Z., Rodzina - zdrowie - choroba, Koncepcje i praktyka pielegniarstwa rodzinnego. Wydawnictwo CZELEJ, Lublin 2001.

3. Rodzina wobec choroby nowotworowej. Portal Onkologiczny zwrotnik RAKA, www.zwrotnikraka.pl [dostęp: 10.07.2015].

4. Jak radzić sobie z emocjonalnymi skutkami choroby nowotworowej? Poradnik dla Pacjentów, Wielkopolskie Centrum Onkologii, Poznań, www.wco.pl [dostęp: 10.07.2015].

5. Kawczyńska-Butrym Z. Wyzwania rodziny: zdrowie, choroba, niepetnosprawność, starość, Wydawnictwo Makmed, Lublin 2008.

6. $\quad$ Smaga A., Mikułowska M., Komorowska A., et al., Rak piersi w Polsce-leczenie to inwestycja, Sequence HC Partners, Warszawa 2014.

7. Stępień R, Wiraszka G. Znaczenie rodziny $w$ adaptacji funkcjonalnej kobiet po radykalnym leczeniu chirurgicznym raka piersi, Problemy Pielęgniarstwa. 2011; 19: $372-377$.

8. Zdolińska M. Wsparcie duchowe dla chorych z rakiem piersi. Portal abcZdrowie, www.portal.abczdrowie.pl [dostęp:10.07.2015].

9. Krasuska ME. Opieka w chorobie nowotworowej, Wydawnictwo YOKAM, Lublin 1997.

10. Meyz J. Jakość życia w chorobie nowotworowej. Centrum Onkologii Instytut im. Marii Skłodowskiej-Curie w Warszawie, Warszawa 1997. 
11. Brzeziński JM, Cierpiałowska L. Zdrowie i choroba Problemy teorii, diagnozy i praktyki. Gdańskie Wydawnictwo Psychologiczne, Gdańsk 2008.

12. Po diagnozie. Poradnik dla pacjentów z choroba nowotworowa i ich rodzin. American Cancer Society, Zakład Psychoonkologii Centrum Onkologii - Instytutu im. Marii Skłodowskiej-Curie w Warszawie, Fundacja Tam i z Powrotem. Primopro, Warszawa 2012.

\title{
Family support:
}

\section{The key determinant of a positive recovery after mastectomy}

\begin{abstract}
Introduction: Cancer requires many sacrifices from both the patient and family members, such as rearranging priorities and the acquisition of new medical care skills. The aim of this study is to present the role played by the family in achieving a successful recovery in women after mastectomy.

Material and Methods: 50 women, Amazons Club members and women participating in a two-week rehabilitation period after mastectomy took part in the research. The dominant research method was monographic and the techniques included user surveys and standardized interviews with elements of free in-depth interview and participant observation.

Results and conclusions: The study revealed that to achieve a successful recovery after mastectomy it is necessary to: relieve the sick woman of household duties; provide medical and emotional care and support in the family. Self-discipline and high psychological resistance of ill woman are important as well.
\end{abstract}

Key words: cancer, family, help, mastectomy 
